\title{
Physiological and sanitary quality, and transmission of fungi associated with Brachiaria brizantha (Hochst. ex. A. Rich.) Stapf seeds submitted to thermal and chemical treatments ${ }^{1}$
}

\author{
Cheila Cristina Sbalcheiro ${ }^{2}$, Solange Carvalho Barrios Roveri José2*, \\ Jennifer Carine Rodrigues da Costa Molina Barbosa ${ }^{3}$
}

\begin{abstract}
The Brazilian pastures establishment success depends on the use of seeds with high physiological and sanitary quality. The aim of this study was to evaluate the effect of thermal and chemical treatments on quality of Brachiaria brizantha, cv. BRS Piatã and pathogen transmission via seed. The treatments included the use of fungicides, detergent, sodium hypochlorite, sulfuric acid and alcohol, as well as thermal treatments. In addition to seeds without treatment, nine treatments were tested. The tests used to assess the physiological quality of the seeds were first and final count of germination test and root protrusion; germination and root protrusion speed index. A transmitting test and filter paper method had been performed for sanitary quality. Fungal lower incidence was observed in seeds treated with alcohol, however, this treatment reduced the physiological quality of the seeds and higher frequency of fungi transmission from seeds to seedlings was observed for Bipolaris sp., Fusarium sp. and Phoma sp. Treatment with sulfuric acid provided a better seed germination performance and reduced the incidence of fungi.
\end{abstract}

Index terms: germination, vigor, seed-seedling, incidence, forage.

\section{Qualidade fisiológica, sanitária e transmissão de fungos associados às sementes de Brachiaria brizantha (Hochst. ex. A. Rich.) Stapf submetidas a tratamentos térmicos e químicos}

\begin{abstract}
RESUMO - O sucesso no estabelecimento das pastagens brasileiras depende da utilização de sementes com boa qualidade fisiológica e sanitária. Objetivou-se com o trabalho avaliar o efeito de tratamentos térmicos e químicos sobre a qualidade fisiológica e sanitária de sementes de Brachiaria brizantha, cultivar BRS Piatã e a transmissão de patógenos via semente. Os tratamentos incluíram o uso de fungicidas, detergente, hipoclorito de sódio, álcool e ácido sulfúrico, além de tratamentos térmicos. Os testes utilizados para a avaliação da qualidade fisiológica das sementes foram primeira contagem e contagem final do teste de germinação e de protrusão radicular; índice de velocidade de germinação e de protrusão radicular. Para a qualidade sanitária foi realizado o método de papel de filtro e o teste de transmissão. Menor incidência fúngica foi observada nas sementes tratadas com álcool, no entanto, esse tratamento reduziu a qualidade fisiológica das sementes e maior frequência de transmissão de fungos das sementes para as plântulas foi observada para Bipolaris sp., Fusarium sp. e Phoma sp. O tratamento com ácido sulfúrico proporcionou melhor desempenho germinativo das sementes e reduziu a incidência de fungos.
\end{abstract}

Termos para indexação: germinação, vigor, semente-plântula, incidência, forrageira.

\section{Introduction}

Brachiaria brizantha (Hochst. ex. A. Rich.) Stapf [syn. Urochloa brizantha (Hochst. ex. A. Rich.) R.D. Webster] is a species originated in Africa and among the cultivars used commercially the Marandu can be cited, a forage grass fairly planted in Brazil, especially in the North and Midwest regions and the BRS Piatã, cultivar noted for producing better quality

${ }^{1}$ Submitted on 09/12/2014. Accepted for publication on 10/27/2014.

${ }^{2}$ Embrapa Recursos Genéticos e Biotecnologia, Caixa Postal 023725, 70770-917 - Brasília, DF, Brasil. forage and with a normally high production of seeds. By presenting different agronomic and adaptive characteristics, this cultivar is recommended to diversify grassland in various culture environments as an alternative to cv. Marandu (Almeida et al., 2009; Quadros et al., 2012).

Successful establishment of Brazilian pastures depends on the use of good quality seeds with high germination, vigor and good phytosanitary quality (Vechiato et al., 2010). However,

${ }^{3}$ Faculdade Anhanguera de Brasília, 72950-000 - Taguatinga, DF, Brasil.

*Corresponding author <solange.jose@embrapa.br> 
most species of tropical forage grasses presents factors that impair the production of good quality seeds, such as the low number of fertile seeds, disuniformity in the emission of inflorescence, irregular flowering within of panicles, high natural shattering, seed dormancy and emergence of weeds in pastures (Martins and Silva, 2003; Bonome et al., 2006). Thus, the presence of seed dormancy is a limiting factor in the germination in the field and under controlled conditions (Garcia and Cícero, 1992; Lacerda et al., 2010).

It is understood by dormancy, the phenomenon in which seemingly viable seeds do not germinate even under favorable environmental conditions (Brasil, 2009; Lacerda et al., 2010). It is remarkable the presence of dormancy in freshly harvested seeds in several species of tropical grasses (Usberti and Martins, 2007; Costa et al., 2011), associated to physiological causes and which are progressively removed during storage (Almeida and Silva, 2004). The recommendations described in the Rules for Testing Seeds - RAS (Brasil, 2009), as well as in most studies conducted to break dormancy in seeds of Brachiaria, the use of chemical scarification with sulfuric acid and thermal treatment are mentioned (Almeida and Silva, 2004; Lacerda et al., 2010; Costa et al., 2011; Custódio et al., 2012).

Alternatives to overcome dormancy can benefit seed quality assessment in laboratory and the development of methods that, being frequently used, allow the marketing of seeds with dormancy partially or totally eliminated (Martins and Silva, 2006).

Besides the physiological quality, seed sanitary quality should be considered. The forage seed production system is threatened by the presence of pathogens, mainly due to the absence of sanity standards to the domestic market, tolerance to seeds infection by pathogens and seed treatments effective techniques (Vechiato et al., 2010).

Thus, the seeds become an efficient mechanism for the introduction and dispersion of various pathogens, which may cause damage from the stand establishment until harvest. The presence of contaminating microorganisms in storage or after the point of physiological maturity also presents a major threat to seed health (Marchi et al., 2007; Marchi et al., 2008; Marchi et al., 2010), therefore it is important to study pathogen transmission via seed to seedling.

Potentially pathogenic fungi such as Bipolaris spp., Curvularia sp., Fusarium sp. and Phoma sp., and storage fungi such as Aspergillus sp., Penicillium sp., Rhizopus sp. associated with Brachiaria seeds have been reported as damage cause to the quality and establishment of forage plants (Marchi et al., 2010; Santos et al., 2014).

Thermotherapy with or without chemical treatment has been used for the eradication of pathogens associated with seeds, and it may reduce pesticide use in vegetable material, in addition to promoting seed germination. This strategy reduces the introduction of new pathogens species in free areas and it can bring benefits to farmers, who can use this practice in the prevention and control of pathogens associated with seed (Tenente et al., 2005).

Thus, in order to the enterprise succeed in deploying pastures, using high physiological and sanitary quality seed is needed. However, information about the physiological and sanitary quality of forage seeds are scarce and lack studies that investigate procedures that benefit getting lots of seeds with higher germination and low infection rate.

Thus, the objective of this study was to evaluate the effect of thermal and chemical treatments on physiological and sanitary quality of Brachiaria brizantha cv. BRS Piatã from two harvests, as well as to analyze the pathogens transmission via seeds to seedlings.

\section{Material and Methods}

The experiments were performed in the Seed Laboratory of Embrapa Genetic Resources and Biotechnology (Brasília, DF). Seeds of Brachiaria brizantha cv. BRS Piatã, 2010 and 2011 harvests, produced in the area of seed production of Sucupira farm (Brasília, DF) were used, and crop seeds system was on bunches. The seeds were received in the laboratory in August 2011 and stayed for 15 days in cold storage to $10^{\circ} \mathrm{C}$ and relative humidity of $30 \%$ when the experiment was installed. The seeds humidity at the beginning of the experiment was $7.9 \%$ and $9.8 \%$ and germination of $29 \%$ and $42 \%$ for seeds harvested in 2010 and 2011, respectively. Seeds were subjected to the following treatments: 1) Profile: untreated seeds; 2) Control: only seeds moistened with ultrapure water at a ratio of 6:1 (seed: water) to simulate the same conditions as other treatments; 3 ) Detergent: seeds immersion in a solution of neutral detergent (10 drops/400 mL water) for 5 minutes under constant agitation and later rinsing; 4) Carbendazim + Thiram $(150+350 \mathrm{SC})$ : seeds moistened with ultrapure water $(6: 1)$ were treated with the product dosage of $300 \mathrm{~mL} / 100 \mathrm{~kg}$ seed; 5) Captan PM 500 (50/kg seed): seeds moistened with ultrapure water $(6: 1)$ were treated with the product dosage of $300 \mathrm{~g} / 100 \mathrm{~kg}$ of seeds; 6) Alcohol 70\%: immersing the seeds in $70 \%$ alcohol for 30 minutes and further rinsing with ultrapure water; 7) Hot hypochlorite: the seeds were placed in Erlenmeyer flask containing warm sodium hypochlorite (1\%) solution and kept in a water bath at $65^{\circ} \mathrm{C}$ for $5 \mathrm{~min}$ and then rinsed with water; 8) Hypochlorite paper: blotter paper was moistened with a solution of sodium hypochlorite $(0.5 \%)$, except for the transmission test in which the seeds were 
placed in a flask containing sodium hypochlorite at $0.5 \%$ in the ratio 2:1 (hypochlorite:seed), kept under constant stirring for 1 minute and rinsed with ultrapure water three times for 2 minutes each and being called hypochlorite solution treatment; 9) Hot water: the seeds were placed in Erlenmeyer flask containing hot ultrapure water and kept in water bath at $65{ }^{\circ} \mathrm{C}$ for 5 minutes; 10) Sulfuric acid: seeds immersion in sulfuric acid for 5 minutes, later rinsed with plentiful ultrapure water and final immersion in ultrapure water for 30 minutes. After the treatments, the seeds were subjected to surface drying in a laminar flow cabinet (sterile environment), except seed treatment profile.

Germination test: for each treatment four replicates of 100 seeds were distributed in four gerbox type boxes, containing two sheets of blotting paper moistened with ultrapure water (except for hypochlorite treatment paper), were used. After sowing, the seeds remained in germination BOD chamber at $20-35{ }^{\circ} \mathrm{C}$ with 16 hours light. The first germination test count was carried out at the third day and the final count after 21 days of sowing by computing the number of normal seedlings, dormant and dead seeds, as recommended by the Rules for Seed Testing (Brasil, 2009). Together with the germination test, the seeds with protruding primary root were count, the germination speed index (GSI) and the root protrusion speed index (RPSI) were performed according to the formula of Maguire (1962).

Health test: for pathology test, four replicates of 400 seeds from each treatment were distributed in gerbox type boxes, containing three sheets of blotting paper moistened with sterile distilled water (except for hypochlorite treatment paper) in laminar flow cabinet. The seeds remained in a germination chamber BOD at $25{ }^{\circ} \mathrm{C}$ with 12 hours light. The sanitary examination was performed seven days after sowing, each seed was individually evaluated with stereomicroscope, observing the occurrence of typical fruiting of fungal growth, and when necessary, the identification was made under an optical microscope. The results were expressed as a percentage of fungi occurrence relating to the number of seeds (incidence) and the rate of fungal incidence control in relation to the profile for each treatment. The sum of all fungi incidences detected in seeds from each treatment and control of the total fungal incidence in relation to treatment profile was adopted as the total fungal incidence.

Pathogen transmission via seed to seedling test: the same treatments of seed pathological analysis were used, replacing "hypochlorite paper" with "hypochlorite solution". The seeds from each treatment were sown in trays containing sterile sieved sand, moistened as its field capacity. 100 seeds per tray were distributed to each treatment, being four replicates of 25 seeds each, and, after sowing, they remained in the germination and BOD chamber at $25^{\circ} \mathrm{C}$ with 12 hours light. Assessments occurred at seven and 14 days after sowing, noting the percentage of seedling emergence and the presence of fungus signs or symptoms in the aerial part of the seedling. All seedlings emerged after 14 days were placed in moist chamber to fungal structures observation.

Statistical Analysis: the experimental design was randomized to the physiological and sanitary analyzes (filter paper) using the factorial (10x2), 10 treatments $\mathrm{x} 2$ harvests. Data were evaluated by analysis of variance and means, compared by Tukey's test at $5 \%$. Analyses were performed in Sisvar (System Analysis of Variance) statistical program (Ferreira, 2011).

\section{Results and Discussion}

There was significant interaction between the harvesting factors and treatments for all tests done, except for the percentage of dormant seeds. The average results are presented in Tables 1 to 6. In general, greater vigor was observed in the treated seeds of the 2010 harvest, compared to the 2011 harvest, in the first count of germination and root protrusion test (Tables 1 and 2), ie, at three days of sowing a higher percentage of normal seedlings and root protrusion on the seeds from the 2010 harvests was found, to most treatments.

The seeds germination of both harvests was similar only when they were treated with sulfuric acid, hypochlorite paper and $70 \%$ alcohol, and the treatment with sulfuric acid was the one that most improved the seeds germination (Tables 1 and 2). The dormancy breaking of the 2011 harvest seeds was only observed in the treatment with sulfuric acid, unlike the seeds of the 2010 harvest, which in addition to sulfuric acid, hot hypochlorite treatment exceeded the germination of untreated seeds (profile).

A similar tendency was observed in the behavior of seeds in the final count of germination test, both in the percentage of normal seedlings (Table 1) as in the root protrusion (Table 2), in the 2011 harvest. Treatment with sulfuric acid outperformed the others, promoting greater germination of the seeds of the newest harvest, 2011. Almeida and Silva (2004) researching the behavior of dormancy in seeds of $B$. dictyoneura found that after thermal treatment of the seeds at a temperature of $85^{\circ} \mathrm{C}$ and sulfuric acid treatment there was a reduction in seed dormancy and improvement in their performance in a similar way for both treatments. However, when the seeds were treated with sulfuric acid and stored for six months, the authors found no increase in normal seedlings or a reduction of dormant seeds, unlike the results observed in this study, in which the seeds were not subjected to any treatment before of the experiment. It was also observed in seeds of the 2010 harvest, that the 
hot hypochlorite treatment, hot water, hypochlorite paper and detergent provided the same performance as the treatment with sulfuric acid and superior performance to profile treatment, with better results on germination (Table 1). Lacerda et al. (2010) found that boiling water for 1-3 minutes was more effective in overcoming dormancy of $B$. brizantha, compared to treatments with gibberellic and sulfuric acid, which does not differ from the control.

Table 1. Mean values of normal seedlings (\%) obtained at first count germination (FCG) and at final count germination (FG) of $B$. brizantha cv. BRS Piatã seeds from two harvests.

\begin{tabular}{lcrcr}
\hline \multirow{2}{*}{\multicolumn{1}{c}{ Treatment }} & \multicolumn{2}{c}{ FCG } & \multicolumn{2}{c}{ FG } \\
\cline { 2 - 5 } & 2010 & 2011 & 2010 & 2011 \\
\hline Sulfuric acid & $42 \mathrm{aA}$ & $47 \mathrm{aA}$ & $53 \mathrm{bA}$ & $63 \mathrm{aA}$ \\
Detergent & $20 \mathrm{aBC}$ & $1 \mathrm{bB}$ & $48 \mathrm{aAB}$ & $32 \mathrm{bB}$ \\
Hypochlorite paper & $3 \mathrm{aE}$ & $0 \mathrm{aB}$ & $43 \mathrm{aABC}$ & $44 \mathrm{aB}$ \\
Hot water & $22 \mathrm{aBC}$ & $0 \mathrm{bB}$ & $43 \mathrm{aABC}$ & $33 \mathrm{bB}$ \\
Hot hypochlorite & $29 \mathrm{aB}$ & $0 \mathrm{bB}$ & $4 \mathrm{aABC}$ & $36 \mathrm{aB}$ \\
Captan & $10 \mathrm{aDE}$ & $0 \mathrm{bB}$ & $40 \mathrm{aABCD}$ & $38 \mathrm{aB}$ \\
Carbendazim+Thiram & $14 \mathrm{aCD}$ & $0 \mathrm{bB}$ & $35 \mathrm{bBCD}$ & $45 \mathrm{aB}$ \\
Control & $20 \mathrm{aBC}$ & $0 \mathrm{bB}$ & $30 \mathrm{bCD}$ & $38 \mathrm{aB}$ \\
Profile & $19 \mathrm{aC}$ & $0 \mathrm{bB}$ & $29 \mathrm{bD}$ & $42 \mathrm{aB}$ \\
Alcohol 70\% & $1 \mathrm{aE}$ & $0 \mathrm{aB}$ & $1 \mathrm{aE}$ & $1 \mathrm{aC}$ \\
\hline
\end{tabular}

Means followed by the same lowercase letter on the line, and capitalized on the column; do not differ statistically by the Tukey's test at $5 \%$ probability.

Table 2. Mean values of root protrusion (\%) obtained at first count (RPFC) and at final count (RP) of $B$. brizantha cv. BRS Piatã seeds germination test from two harvests.

\begin{tabular}{lcrlc}
\hline \multirow{2}{*}{\multicolumn{1}{c}{ Treatment }} & \multicolumn{2}{c}{ RPFC } & \multicolumn{2}{c}{ RP } \\
\cline { 2 - 5 } & 2010 & 2011 & 2010 & 2011 \\
\hline Sulfuric acid & $42 \mathrm{aA}$ & $47 \mathrm{aA}$ & $57 \mathrm{aA}$ & $64 \mathrm{aA}$ \\
Detergent & $20 \mathrm{aBC}$ & $5 \mathrm{bB}$ & $49 \mathrm{aABC}$ & $32 \mathrm{bC}$ \\
Hypochlorite paper & $3 \mathrm{aE}$ & $0 \mathrm{aB}$ & $45 \mathrm{aABC}$ & $45 \mathrm{aBC}$ \\
Hot water & $22 \mathrm{aBC}$ & $5 \mathrm{bB}$ & $47 \mathrm{aABC}$ & $33 \mathrm{bBC}$ \\
Hot hypochlorite & $29 \mathrm{aB}$ & $3 \mathrm{bB}$ & $50 \mathrm{aAB}$ & $37 \mathrm{bBC}$ \\
Captan & $10 \mathrm{aDE}$ & $0 \mathrm{bB}$ & $47 \mathrm{aABC}$ & $39 \mathrm{bBC}$ \\
Carbendazim+Thiram & $14 \mathrm{aCD}$ & $1 \mathrm{bB}$ & $41 \mathrm{aBC}$ & $46 \mathrm{aB}$ \\
Control & $20 \mathrm{aBC}$ & $2 \mathrm{bB}$ & $40 \mathrm{aBC}$ & $39 \mathrm{aBC}$ \\
Profile & $19 \mathrm{aC}$ & $1 \mathrm{bB}$ & $37 \mathrm{aC}$ & $42 \mathrm{aBC}$ \\
Alcohol 70\% & $1 \mathrm{aE}$ & $0 \mathrm{aB}$ & $2 \mathrm{aD}$ & $1 \mathrm{aD}$ \\
\hline
\end{tabular}

Means followed by the same lowercase letter on the line, and capitalized on the column; do not differ statistically by the Tukey's test at $5 \%$ probability.

Costa et al. (2011) found that storage for 21 months was more effective for overcoming $B$. humidicola seed dormancy than acid scarification or germination promoting substances application. However, seeds stored for periods longer than 12 months may have lower quality and treatments with sulfuric acid does not promote germination increase, as evidenced by Custódio et al. (2012), in B. brizantha seeds lots. Paniago et al. (2014) found that the storage time did not provide $B$. humidicola seed quality increase nor reduced the percentage of dormant seeds. However, the study period was only 90 days of storage. In this study, despite the seeds germination of the 2010 harvest was low, treatment with sulfuric acid provided an $82 \%$ percentage increase of normal seedlings compared to untreated seeds (profile), with 29\% germination. For seeds of the 2011 harvest, this increase was 50\% (Table 1). These results corroborate those obtained by Câmara and StacciariniSeraphin (2002), who observed that seeds of B. brizantha stored for sixteen months at laboratory conditions showed poor germination, around $23 \%$, but maintained viability. It was expected that the percentage of dormant seeds in 2011 harvest was higher, since the seeds are the newest crop. However, the percentage of dormant seeds of the 2011 harvest was $25 \%$ and for the 2010 harvest, that number was $46 \%$. A higher percentage of dead seeds of the 2011 harvest may have contributed to reduce the proportion of dormant seeds of this harvest (Table 3). It is clear that the storage time may promote dormancy breaking, but the history of seeds must be considered.

Table 3. Mean values of dormant seeds (DorS) and dead seeds (DS) obtained at B. brizantha cv. BRS Piatã seeds final germination.

\begin{tabular}{llll}
\hline \multicolumn{1}{c}{ Treatment } & $\begin{array}{l}\text { DorS } \\
(\%)\end{array}$ & \multicolumn{2}{c}{$\begin{array}{c}\text { DS } \\
(\%)\end{array}$} \\
\hline & & 2010 & 2011 \\
\hline Sulfuric acid & $19 \mathrm{C}$ & $15 \mathrm{bAB}$ & $25 \mathrm{aDE}$ \\
Detergent & $32 \mathrm{~B}$ & $9 \mathrm{bABC}$ & $43 \mathrm{aABC}$ \\
Hypochlorite paper & 27 BC & $9 \mathrm{bABC}$ & $39 \mathrm{aBC}$ \\
Hot water & $29 \mathrm{~B}$ & $9 \mathrm{bABC}$ & $50 \mathrm{aA}$ \\
Hot hypochlorite & $31 \mathrm{~B}$ & $4 \mathrm{bC}$ & $44 \mathrm{aAB}$ \\
Captan & $33 \mathrm{~B}$ & $7 \mathrm{bBC}$ & $36 \mathrm{aBC}$ \\
Carbendazim+Thiram & $30 \mathrm{~B}$ & $14 \mathrm{bABC}$ & $33 \mathrm{aCD}$ \\
Control & $31 \mathrm{~B}$ & $19 \mathrm{bA}$ & $39 \mathrm{aABC}$ \\
Profile & $35 \mathrm{~B}$ & $11 \mathrm{bABC}$ & $37 \mathrm{aBC}$ \\
Alcohol 70\% & $86 \mathrm{~A}$ & $5 \mathrm{bBC}$ & $21 \mathrm{aE}$ \\
\hline Mean DorS (\%) harvest 2010 & $46 \mathrm{~A}$ & & \\
Mean DorS (\%) harvest 2011 & $25 \mathrm{~B}$ & & \\
\hline
\end{tabular}

*There was no interaction between harvests and treatments for this variable. Means followed by the same lowercase letter on the line, and capitalized on the column; do not differ statistically by the Tukey's test at $5 \%$ probability.

In Table 4 the data obtained for the germination speed rate can be observed, measured by the germination speed index (GSI) and root protrusion (RPSI). Higher values for the index means 
more vigorous seeds. Treatment with sulfuric acid provided the best results, outperforming the other treatments, and these rates were higher in the seeds of the 2011 harvest, confirming the results obtained by Dias and Toledo (1993), Lago and Martins (1998) and Martins and Silva (2006) who also found that the best performance in germination and dormancy breaking of $B$. brizantha seeds was using sulfuric acid treatment, even during the storage for six months (Sallum et al., 2010).

Treatment with $70 \%$ alcohol reduced physiological seed quality, and on germination test the values observed in the two harvests were statistically equal, within $1 \%$ normal seedlings (Table 1). Seed vigor was also negatively affected by this treatment, regardless of the harvest, providing the worst results (Table 4). Although treatment with sulfuric acid is effective in breaking dormancy, it can also cause injuries to the seeds (Macedo et al., 1994; Meschede et al., 2004). As mentioned by Garcia and Cícero (1992) and Dias and Alves (2008), responses to different treatments to overcome dormancy vary with the history and age of seeds, storage conditions, among other factors, and may not cause the expected effect. Undesirable effect can also be observed when the seed lot to be treated presents dormant and not dormant seeds. In this research, although the seeds are from different harvests, ie, different ages, treatment with sulfuric acid caused no injuries to them, favoring both germination and seed vigor.

Regarding the sanitary quality of seeds, on the 2010 harvest the incidence of the following fungi were observed: Alternaria spp., Aspergillus flavus, Aspergillus niger, Aspergillus ochraceus, Bipolaris spp., Chaetomium sp., Cladosporium sp., Curvularia sp., Fusarium sp., Penicillium sp., Phoma sp., Pithomyces sp., Rhizopus sp. and Trichoderma sp. (Table 5). On the 2011 harvest, the following fungi were observed: Alternaria spp., A. flavus, A. niger, Bipolaris spp., Chaetomium sp., Curvularia sp., Fusarium sp., Penicillium sp., Phoma sp. and Rhizopus sp. When comparing the two harvests, higher total fungal incidence in seeds of the 2011 season was observed, including the untreated seeds (profile), which may have provided an increase in the percentage of dead seeds in this harvest, as seen in Table 3. Among the fungi identified in this study, six were identified by Mallmann et al. (2013) in B. brizantha cv. BRS Piatã: Alternaria sp., Bipolaris sp., Cladosporium sp., Curvularia sp., Fusarium sp. and Phoma sp. and 10 were observed by Santos et al. (2014): Aspergillus niger, Bipolaris sp., Chaetomium sp., Curvularia sp., Fusarum sp., Penicillium sp., Phoma sp., Pithomyces sp., Rhizopus sp., Trichoderma sp.

Table 4. Mean values of germination speed index (GSI) and root protrusion speed index (RPSI) obtained at $B$. brizantha cv. BRS Piatã seeds germination test from two harvests.

\begin{tabular}{lcccc}
\hline \multirow{2}{*}{\multicolumn{1}{c}{ Treatment }} & \multicolumn{2}{c}{ GSI } & \multicolumn{2}{c}{ RPSI } \\
\cline { 2 - 5 } & 2010 & 2011 & 2010 & 2011 \\
\hline Sulfuric acid & $16 \mathrm{bA}$ & $26 \mathrm{aA}$ & $16 \mathrm{bA}$ & $26 \mathrm{aA}$ \\
Detergent & $6 \mathrm{aB}$ & $5 \mathrm{bB}$ & $6 \mathrm{aB}$ & $7 \mathrm{aB}$ \\
Hypochlorite paper & $5 \mathrm{aB}$ & $6 \mathrm{aB}$ & $5 \mathrm{bB}$ & $7 \mathrm{aB}$ \\
Hot water & $6 \mathrm{aB}$ & $5 \mathrm{bB}$ & $6 \mathrm{aB}$ & $6 \mathrm{aB}$ \\
Hot hypochlorite & $6 \mathrm{aB}$ & $5 \mathrm{aB}$ & $7 \mathrm{aB}$ & $6 \mathrm{aB}$ \\
Captan & $5 \mathrm{aB}$ & $5 \mathrm{aB}$ & $6 \mathrm{aB}$ & $6 \mathrm{aB}$ \\
Carbendazim+Thiram & $5 \mathrm{aB}$ & $6 \mathrm{aB}$ & $5 \mathrm{bB}$ & $7 \mathrm{aB}$ \\
Control & $4 \mathrm{aB}$ & $5 \mathrm{aB}$ & $5 \mathrm{bB}$ & $7 \mathrm{aB}$ \\
Profile & $4 \mathrm{aB}$ & $6 \mathrm{aB}$ & $5 \mathrm{bB}$ & $7 \mathrm{aB}$ \\
Alcohol 70\% & $0 \mathrm{aC}$ & $0 \mathrm{aC}$ & $0 \mathrm{aC}$ & $0 \mathrm{aC}$ \\
\hline
\end{tabular}

Means followed by the same lowercase letter on the line, and capitalized on the column; do not differ statistically by the Tukey's test at $5 \%$ probability.

Table 5. Fungal incidence and incidence control in B. brizantha cv. BRS Piatã seeds from two harvests.

\begin{tabular}{|c|c|c|c|c|c|c|}
\hline \multirow{2}{*}{ Treatment } & \multicolumn{3}{|c|}{ Total Fungal Incidence (\%) } & \multicolumn{3}{|c|}{ Incidence control $*(\%)$} \\
\hline & 2010 & 2011 & Means & 2010 & 2011 & Means \\
\hline Profile & $38 \mathrm{bB}$ & $118 \mathrm{aB}$ & $78 \mathrm{~B}$ & & & \\
\hline Control & $39 \mathrm{bB}$ & $123 \mathrm{aB}$ & $81 \mathrm{~B}$ & $0 \mathrm{aD}$ & $0 \mathrm{aE}$ & $0 \mathrm{E}$ \\
\hline Detergent & $60 \mathrm{bA}$ & $124 \mathrm{aB}$ & $92 \mathrm{~A}$ & $0 \mathrm{aD}$ & $0 \mathrm{aE}$ & $0 \mathrm{E}$ \\
\hline Carbendazim + Thiram & $2 \mathrm{bD}$ & $42 \mathrm{aD}$ & $22 \mathrm{DE}$ & $94 \mathrm{aA}$ & $64 \mathrm{bC}$ & $79 \mathrm{~B}$ \\
\hline Captan & $3 \mathrm{bD}$ & $20 \mathrm{aE}$ & $11 \mathrm{FG}$ & $92 \mathrm{aA}$ & $83 \mathrm{bB}$ & $88 \mathrm{AB}$ \\
\hline Alcohol 70\% & $7 \mathrm{aD}$ & $3 \mathrm{aF}$ & $5 \mathrm{G}$ & $82 \mathrm{bA}$ & $97 \mathrm{aA}$ & $90 \mathrm{~A}$ \\
\hline Hot hypochlorite & $21 \mathrm{aC}$ & $11 \mathrm{bEF}$ & $16 \mathrm{EF}$ & $44 \mathrm{bC}$ & $90 \mathrm{aAB}$ & $67 \mathrm{C}$ \\
\hline Hypochlorite paper & $48 \mathrm{bAB}$ & $137 \mathrm{AA}$ & $93 \mathrm{~A}$ & $0 \mathrm{aD}$ & $0 \mathrm{aE}$ & $0 \mathrm{E}$ \\
\hline Hot water & $12 \mathrm{bCD}$ & $78 \mathrm{AC}$ & $45 \mathrm{C}$ & $67 \mathrm{aB}$ & $34 \mathrm{bD}$ & $50 \mathrm{D}$ \\
\hline Sulfuric acid & $13 \mathrm{bCD}$ & $41 \mathrm{aD}$ & $27 \mathrm{D}$ & $65 \mathrm{aB}$ & $65 \mathrm{aC}$ & $65 \mathrm{C}$ \\
\hline Means & $24 \mathrm{~b}$ & $70 \mathrm{a}$ & & $44 \mathrm{a}$ & $43 \mathrm{a}$ & \\
\hline
\end{tabular}

\footnotetext{
* Total fungal incidence control in relation to profile treatment. Means followed by the same lowercase letter on the line, and capitalized on the column; do
} not differ statistically by the Tukey's test at $5 \%$ probability. 
The lowest total fungal incidences in the seeds of the 2010 harvest were observed in the treatments with Carbendazim + Thiram (2\%), Captan (3\%), alcohol 70\% $(7 \%)$, hot water $(12 \%)$ e sulfuric acid $(13 \%)$. For the seeds of the 2011 harvest, the lowest values were 3\%, 11\% and $20 \%$ for treatments with alcohol, hot hypochlorite and Captan, respectively. As for controlling the fungi incidence on seeds in relation to treatment profile, it was observed that the alternative alcohol treatment had the highest control percentage on seeds of the 2011 harvest and did not differ statistically from fungicide treatments in 2010 harvest (Table 5). Comparing the results in Table 5 with those shown in Tables 1 and 2, treatments with hot water and sulfuric acid were effective for improving the physiological quality, assessed at the final count of testing and seed of the 2010 harvest sanitary quality.

According to Martins et al. (2001) treatment with sulfuric acid reduces the incidence of plant pathogens. Similar results were observed in this study, for the two crops analyzed, however, seed treatment with sulfuric acid was not superior to treatment with fungicides and $70 \%$ alcohol in relation to the incidence of pathogens.

Although alcohol treatment has been effective in controlling plant pathogens, in two harvests, this treatment has damaged seed performance in tests that assessed the physiological quality of seeds. Observing the values obtained in the germination test (Table 1), which is the standard for seed quality evaluation for marketing purposes, it can be seen that, except for alcohol, other treatments did not reduce seed germination, compared to seed treatment profile. However, seed treatment with sulfuric acid provided higher germination and reduced overall incidence of fungi by $65 \%$ for the two harvests, being a viable alternative for improving the physiological and sanitary quality of the seeds. This treatment reduced the incidence of the following fungi: Alternaria spp., A. ochraceus, Bipolaris sp., Chaetomium sp., Cladosporium sp., Curvularia sp., Fusarium spp., Phoma sp., Rhizopus sp. and Trichoderma sp., in relation to profile treatment seed and in a similar way to treatments with fungicides, and it was more effective in controlling Alternaria spp. and Bipolaris sp., than fungicides. Probably, sulfuric acid acted in reducing the inoculum potential present in the $B$. brizantha $\mathrm{cv}$. BRS Piatã seed, becoming an alternative method for controlling pathogens.

In the transmission of pathogens via seed sowed on sand testing (Table 6), the occurrence of Aspergillus sp., Bipolaris sp., Curvularia sp., Fusarium spp., Penicillium sp., Phoma sp. e Rhizopus sp. pathogens was observed, confirming the transmission of pathogens present in the seeds to seedlings since those fungi were detected in seed pathology test. These fungi, for having the ability to infest/infect and be transmitted by seed, besides reducing germination, they become a risk to the forage crops, especially under favorable environmental conditions and in the absence of an efficient controlling method. Santos et al. (2014) observed the transmission of Bipolaris sp. and Curvularia sp. from B. brizantha seeds for seedlings and found that the Bipolaris sp. fungus, is damaging the seedlings of the Brachiaria, Crotalaria and Panicum genera.

In 2010 harvest (Table 6), seed treatment with hot water and sulfuric acid reduced the percentage of seedlings with pathogens, as well as treatments with Carbendazim+Thiram and Captan fungicides. Similar results were observed for fungal incidence (Table 5) to the same treatments. Seed treatment with $70 \%$ alcohol interfered with seedling emergence in sand, corroborating the results obtained in this study on the germination test. However, the two seedlings that emerged from this treatment had Bipolaris sp. fungus, ie, even being the best treatment to control pathogens associated with seed in filter paper test, the seedlings that emerged were seen to be infected by fungi.

In the 2011 harvest treatment of seeds with hot sodium hypochlorite reduced the percentage of pathogens infected seedling in relation to the profile (Table 6). It was observed that the treatment of seeds with fungicides was not efficient in controlling Bipolaris sp. It is important to mention that the active principles Captan and Carbendazim do not present the toxic action to Bipolaris, Curvularia, Alternaria and Drechslera, according to Reis et al. (2001).

Differences in results for the same treatments between harvests were observed, indicating that thermal treatment associated or not with chemical treatment make the fungi incidences associated with $B$. brizantha seeds be variable in different harvests, possibly due to the position, way of infection and colonization of the microorganism in the seed, initial inoculum amount and time exposed to the treatment.

Although sulfuric acid is effective in promoting germination, as well as at the fungi incidence control, this treatment poses risks to the health, and handling precautions should be taken. Therefore, the study of alternative and effective methods should be investigated. In the present study, it was found that the thermal treatment with sodium hypochlorite and water may be an alternative to improve the seeds physiological and sanitary quality. 
Table 6. Pathogen transmission via seed for de B. brizantha cv. BRS Piatã seedlings from two harvests.

\begin{tabular}{|c|c|c|c|c|c|c|c|c|c|}
\hline \multirow{2}{*}{ Treatments } & \multirow{2}{*}{ Harvest } & \multirow{2}{*}{$\begin{array}{c}\text { Emerging } \\
\text { seedlings }(\%)\end{array}$} & \multicolumn{7}{|c|}{$\%$ of seedlings with pathogen } \\
\hline & & & Asp.* & Bip. & Cur. & Fus. & Pen. & Pho. & Rhi. \\
\hline \multirow{2}{*}{ Profile } & 2010 & 45 & 16 & 4 & 0 & 29 & 0 & 7 & 0 \\
\hline & 2011 & 29 & 0 & 55 & 7 & 38 & 0 & 31 & 0 \\
\hline \multirow{2}{*}{ Control } & 2010 & 49 & 0 & 0 & 0 & 80 & 0 & 31 & 2 \\
\hline & 2011 & 34 & 0 & 32 & 0 & 44 & 0 & 18 & 0 \\
\hline \multirow{2}{*}{ Detergent } & 2010 & 20 & 0 & 0 & 0 & 10 & 10 & 0 & 15 \\
\hline & 2011 & 29 & 3 & 48 & 0 & 31 & 0 & 24 & 0 \\
\hline \multirow{2}{*}{ Carbendazim + Thiram } & 2010 & 44 & 0 & 7 & 0 & 2 & 0 & 0 & 0 \\
\hline & 2011 & 41 & 0 & 98 & 0 & 15 & 0 & 5 & 0 \\
\hline \multirow{2}{*}{ Captan } & 2010 & 49 & 2 & 0 & 0 & 0 & 0 & 0 & 0 \\
\hline & 2011 & 42 & 0 & 38 & 0 & 26 & 0 & 26 & 0 \\
\hline \multirow{2}{*}{ Alcohol 70\% } & 2010 & 2 & 0 & 100 & 0 & 0 & 0 & 0 & 0 \\
\hline & 2011 & 4 & 0 & 50 & 0 & 0 & 0 & 25 & 0 \\
\hline \multirow{2}{*}{ Hot hypochlorite } & 2010 & 42 & 12 & 5 & 0 & 0 & 0 & 0 & 0 \\
\hline & 2011 & 43 & 2 & 23 & 2 & 7 & 0 & 14 & 0 \\
\hline \multirow{2}{*}{ Hypochlorite solution } & 2010 & 31 & 0 & 71 & 0 & 0 & 0 & 0 & 0 \\
\hline & 2011 & 32 & 0 & 53 & 0 & 44 & 0 & 25 & 0 \\
\hline \multirow{2}{*}{ Hot water } & 2010 & 37 & 0 & 0 & 0 & 3 & 0 & 0 & 0 \\
\hline & 2011 & 31 & 0 & 29 & 0 & 48 & 0 & 7 & 0 \\
\hline \multirow{2}{*}{ Sulfuric acid } & 2010 & 57 & 0 & 0 & 0 & 0 & 16 & 0 & 0 \\
\hline & 2011 & 53 & 13 & 34 & 0 & 30 & 0 & 42 & 0 \\
\hline
\end{tabular}

*Asp.=Aspergillus sp.; Bip.=Bipolaris sp.; Cur.=Curvularia sp.; Fus.=Fusarium sp.; Pen.=Penicillium sp.; Pho.=Phoma sp.; Rhi.=Rhizopus sp.

\section{Conclusions}

The treatment with sulfuric acid provides better seed germination performance and contributes to reducing the fungi incidence.

Minor fungal incidences are observed in seeds treated with alcohol, but this treatment is highly detrimental to physiological seed quality.

Bipolaris sp., Fusarium sp. and Phoma sp. fungi have higher seed to seedling transmission frequency in Brachiaria brizantha cv. Piatã.

\section{References}

ALMEIDA, R.G.; COSTA, J.A.A.; KICHEL, A.N.; ZIMMER, A.H. Taxas e Métodos de Semeadura para Brachiaria brizantha cv. BRS Piatã em Safrinha. Comunicado Técnico, 113, Campo Grande, 2009. http://ainfo. cnptia.embrapa.br/digital/bitstream/CNPGC-2010/13218/1/COT113.pdf

ALMEIDA, C.R.; SILVA, W.R. Comportamento da dormência em sementes de Brachiaria dictyoneura cv. Llanero submetidas às ações do calor e do ácido sulfúrico. Revista Brasileira de Sementes, v.26, n.1, p.44-49, 2004. http://www.scielo.br/pdf/rbs/v26n1/a07v26n1.pdf

BONOME, L.T.S.; GUIMARÃES, R.M.; OLIVEIRA, J.A.; ANDRADE, V.C.; CABRAL, P.S. Efeito do condicionamento osmótico em sementes de Brachiaria brizantha cv. Marandu. Ciência e Agrotecnologia, v.30, n.3, p.422-428, 2006. http://www.scielo.br/pdf/cagro/v30n3/v30n3a06.pdf
BRASIL. Ministério da Agricultura, Pecuária e Abastecimento. Regras para análise de sementes. Ministério da Agricultura, Pecuária e Abastecimento. Secretaria de Defesa Agropecuária. Brasília: MAPA/ACS, 2009. 395p. http:// www.agricultura.gov.br/arq_editor/file/2946_regras_analise_sementes.pdf

CÂMARA， H.H.L.L.; STACCIARINI-SERAPHIN， E. Germinação de sementes de Brachiaria brizantha cv. Marandu sob diferentes períodos de armazenamento e tratamento hormonal. Pesquisa Agropecuária Tropical, v.32, n.1, p.21-28, 2002. http://www.revistas.ufg.br/index.php/pat/article/view/2436

COSTA, C.J.; ARAÚJO, R.B.; VILLAS BÔAS, H.D. C. Tratamentos para a superação de dormência em sementes de Brachiaria humidicola (Rendle) Schweick. Pesquisa Agropecuária Tropical, v.41, n.4, p.519-524, 2011. http://www.scielo.br/pdf/Pat/v41n4/a11v41n4.pdf

CUSTÓDIO, C.C.; DAMASCENO, L.R.; NETO, N.B.M. Imagens digitalizadas na interpretação do teste de tetrazólio em sementes de Brachiaria brizantha. Revista Brasileira de Sementes, v.34, n.2, p.334-341, 2012. http://www.scielo.br/pdf/rbs/v34n2/20.pdf

DIAS, M.C.L.L.; ALVES, S.J. Avaliação da viabilidade de sementes de Panicum maximum Jacq pelo teste de tetrazólio. Revista Brasileira de Sementes, v.30, n.3, p.152-158, 2008. http://www.scielo.br/pdf/rbs/v30n3/20.pdf

DIAS, D.C.F.S.; TOLEDO, F.F. Germinação e incidência de fungos em testes com sementes de Brachiaria brizantha (Hochst ex A. Rich.) Stapf. Scientia Agricola, v.50, n.1, p.68-76, 1993. http://www.scielo.br/pdf/sa/v50n1/11.pdf

FERREIRA, D.F. SISVAR: a computer statistical analysis system. Ciência e Agrotecnologia, v.35, n.6, p.1039-1042, 2011. http://www.scielo.br/pdf/ cagro/v35n6/a01v35n6 
GARCIA, J.; CÍCERO, S.M. Superação de dormência em sementes de Brachiaria brizantha Marandu. Scientia Agricola, v.49, n.1, p.9-13, 1992. http://www.scielo.br/pdf/sa/v49nspe/02.pdf

LACERDA, M.J.R.; CABRAL, J.S.R.; SALES, J.F.; FREITAS, K.R.; FONTES, A.J. Superação da dormência de sementes de Brachiaria brizantha cv. "Marandu". Semina: Ciências Agrárias, v.31, n.4, p.823-828, 2010. http:// www.uel.br/portal/frm/frmOpcao.php?opcao=http://www.uel.br/revistas/uel/ index.php/semagrarias

LAGO, A.A.; MARTINS, L. Qualidade fisiológica de sementes de Brachiaria brizantha. Pesquisa Agropecuária Brasileira, v.33, n.2, p.199-204, 1998. http://seer.sct.embrapa.br/index.php/pab/article/view/4832/6950

MACEDO, E.C.; GROTH, D.; LAGO, A.A. Efeito de escarificação com ácido sulfúrico na germinação de sementes de Brachiaria humidicola (RENDLE) SCHWEICK. Pesquisa Agropecuária Brasileira, v.29, n.3, p.455-460, 1994.

MAGUIRE, J.D. Speeds of germination and seedling emergence and vigor. Crop Science, v.2, n. 2, p.176-177, 1962.

MALLMANN, G.; VERZIGNASSI, J.R.; FERNANDES, C.D.; SANTOS, J.M.; VECHIATO, M.H.; INÁCIO, C.A.; BATISTA, M.V.; QUEIROZ, C.A. Fungos e nematoides associados a sementes de forrageiras tropicais. Summa Phytopathologica, v.39, n.3, p.201-203, 2013. http://www.scielo.br/pdf/sp/ v39n3/a10v39n3.pdf

MARCHI, C.E.; FERNANDES, C.D.; BORGES, C.T.; SANTOS, J.M.; JERBA, V.F.; TRENTIN, R.A.; GUIMARÃES, L.R.A. Nematofauna fitopatogênica de sementes comerciais de forrageiras tropicais. Pesquisa Agropecuária Brasileira, v.42, n.5, p.655-660, 2007. http://www.scielo.br/ pdf/pab/v42n5/07.pdf

MARCHI, C.E.; FERNANDES, C.D.; ANACHE, F.C.; JERBA, V.F.; FABRIS, L.R. Quimio e termoterapia em sementes e aplicação de fungicidas em Brachiaria brizantha como estratégias no manejo do carvão. Summa Phytopathologica, v.34, n.4, p.321-325, 2008. http://www.scielo.br/pdf/sp/ v34n4/v34n4a04.pdf

MARCHI, C.E.; FERNANDES, C.D.; BUENO, M.L.; BATISTA, M.V.; FABRIS, L.R. Fungos veiculados por sementes comerciais de braquiária. Arquivo Instituto Biológico, v.77, n.1, p.65-73, 2010. http://www.biologico. sp.gov.br/docs/arq/v77_1/marchi.pdf

MARTINS, L.; SILVA W.R.; ALMEIDA, R.R. Sanidade em sementes de Brachiaria brizantha (Hochst. ex. A. Rich) Stapf submetidas a tratamentos térmicos e químico. Revista Brasileira de Sementes, v.23, n.2, p.117-120, 2001. http://www.abrates.org.br/revista/artigos/2001/v23n2/artigo17.pdf

MARTINS, L.; SILVA, W.R. Efeitos imediatos e latentes de tratamentos térmico e químico em sementes de Brachiaria brizantha cultivar Marandu. Bragantia, v.62, n.1, p.81-88, 2003. http://www.scielo.br/pdf/brag/ v62n1/18504.pdf

MARTINS, L.; SILVA, W.R. Ações fisiológicas do calor e do ácido sulfúrico em sementes de Brachiaria brizantha cultivar Marandu. Bragantia, v.65, n.3, p.495-500, 2006. http://www.scielo.br/pdf/brag/v65n3/a16v65n3.pdf
MESCHEDE, D.K. SALES, J.G.C.; BRACCINI, A.L.; SCAPIM, C.A. SCHUAB, S.R.P.. Tratamentos para superação da dormência das sementes de capim-braquiária cultivar Marandu. Revista Brasileira de Sementes, v.26, n.2, p.15-19, 2004. http://www.scielo.br/pdf/rbs/v26n2/24492.pdf

PANIAGO, B. C.; PEREIRA, S.R.; RODRIGUES, A.P.D'A.C.; LAURA, V.A, Dormência pós-colheita de sementes de Urochloa humidicola (Rendle) Morrone e Zuloaga. Informativo ABRATES, v.24, n.1, p.22-26, 2014. http://www.abrates. org.br/portal/images/Informativo/v24_n1/004_2014_Silvia_Rahe.pdf

QUADROS, D.G.; ANDRADE, A.P.; OLIVEIRA, G.C.; OLIVEIRA, E.P.; MOSCON, E.S. Componentes da produção e qualidade de sementes dos cultivares marandu e xaraés de Brachiaria brizantha (Hochst. ex A. Rich.) Stapf colhidas por varredura manual ou mecanizada. Semina: Ciências Agrárias, v.33, n.5, p.2019-2028, 2012. http://www.uel.br/revistas/uel/index. php/semagrarias/article/view/9712/11581

REIS, E.M.; FORCELINI, C.A.; REIS, A.C. Manual de fungicidas: Guia para o controle químico de doenças de plantas. Florianópolis: Insular, 2001. 176p.

SALLUM, M.S.S.; ALVES, D.S.; AGOSTINI, E.A.T.; MACHADO NETO, N.B. Neutralização da escarificação química sobre a germinação de sementes de Brachiaria brizantha cv. Marandu. Revista Brasileira de Ciências Agrárias, v.5, n.3, p.315-321, 2010. http://agraria.pro.br/sistema/index. php?journal $=$ agraria $\&$ page $=$ article $\&$ op $=$ view $\&$ path $\% 5 \mathrm{~B} \% 5 \mathrm{D}=$ agraria v5i3a603\&path $\% 5 \mathrm{~B} \% 5 \mathrm{D}=748$

SANTOS, G.R ; TSCHOEKE, P.H.; SILVA, L.G; SILVEIRA, M.C.A.C.; REIS, H.B.; BRITO, D.R.; CARLOS, D.S. Sanity analysis, transmission and pathogenicity off fungi associated with forage plant seeds in tropical regions of Brazil. Journal of Seed Science, v.36, n.1, p.54-62, 2014. http://www. scielo.br/pdf/jss/v36n1/a07v36n1.pdf

TENENTE, R. C. V.; GONZAGA, V.; SOUSA, A.I.M.; SANTOS, D.S Aplicação de tratamentos térmicos e químicos em sementes de beterraba importada, na erradicação de Ditylenchus dipsaci (Kuhn, 1857) Filipjev, 1936. Embrapa Recursos Genéticos e Biotecnologia, 2005. 8p. (Circular Técnica 36). http://www.cenargen.embrapa.br/clp/publicacoes/cit/2005/ cit036.pdf

USBERTI, R.; MARTINS, L. Sulphuric acid scarification effects on Brachiaria brizantha, B. humidicola and Panicum maximum seed dormancy release. Revista Brasileira de Sementes, v.29, p.143-147, 2007. http://www. scielo.br/pdf/rbs/v29n2a20.pdf

VECHIATO, M.H.; APARECIDO, C.C.; FERNANDES, C.D. Frequência de fungos em lotes de sementes comercializadas de Brachiaria e Panicum. Arquivos Instituto Biológico. Documento Técnico n.4, p.1-11, 2010. http:// www.biologico.sp.gov.br/docs/dt/DT 07 2010.pdf 